\title{
Borderline Resectable Mass
}

National Cancer Institute

\section{Source}

National Cancer Institute. Borderline Resectable Mass. NCI Thesaurus. Code C157347.

A tumor mass finding that refers to a continuum between resectable and locally advanced unresectable disease. 